\title{
Graphic Publishers and the Bibliographer: An Introduction and Checklist ${ }^{1}$
}

David B. Kotin

IN I926, JUST OVER A YEAR AFTER HE FOUNDED GRAPHIC PUBLISHERS, THE thirty-six year old Henry C. Miller, a printer-turned-publisher, wrote to Mrs. Frederick Philip Grove,

We feel that we have a mission to perform here in Canada: we may be idealistic, but we are young and we can work. We are not after any tremendous salaries or sumptuous offices. We believe that all this will come when we have got to the place where we want to be, recognized as THE Canadian publishers and not giving a hoot about our friends to the south of us. We believe that within a year we will have the strongest group of writers in Canada publishing with us, and we believe that we will give them so much satisfaction that no other house can take them away from us. ${ }^{2}$

Graphic Publishers, a small, ambitious, almost visionary commercial publishing house in Ottawa, issued its first book in 1925 and its last in the year of its bankruptcy in 1932. During these seven years Graphic's avowed purpose and raison d'être was to publish popular books for the Canadian market; books produced only in Canada, specifically Ottawa, using only Canadian materials. At least three of the seven years were marked by acute financial and organizational problems. In 1929 there was a major re-organization and re-incorporation, yet the Graphic canon consists of at least eighty-three titles; so, as Miller wrote to Mrs. Grove, the firm was young, energetic, and dedicated to an ideal in a very risky and pragmatic business.

What should be included in the Graphic canon? This question is more complex than it may seem, for there are at least five other associated and / or subsidiary imprints that must be considered in order to present an accurate picture of the activity and influence of the firm. The Graphic imprint itself underwent several significant changes in accidentals. The earliest imprint was simply 'Ottawa The Graphic Publishers' (no punctuation). ${ }^{3}$ Between late 1925 and 1929 the imprint generally read 'The Graphic Publishers, Limited Ottawa, Canada'. After the firm was re-incorporated and Miller ousted in I929, the imprint was changed to 'Graphic Publishers Limited Ottawa Canada'.

Usually appearing in Graphic books was the thunderbird device that Alan 
Beddoe designed for Miller sometime before 1925 when Miller was printing under the name Graphic Advertisers. 'The thunderbird: a mark of Canadian quality' is a phrase that is featured along with the device in many Graphic Publishers' books. The text from a promotional leaflet relating to the thunderbird symbol is illustrative of the nationalistic zeal so characteristic of the firm:

The Thunder Bird is one of the most ancient and honoured of mystical figures of the Canadian Indian. It stood for the tremendous energy and power that man felt in thunder and lightning. It represented a spirit of energy, strength, efficiency and success. It stood for the finer things of life - of what we understand today by intellect, advancement and consciousness.

The Thunder Bird (Trade Mark of Graphic) to-day stands for all that is mentioned above, is used as a mark of Canadian quality and service and is a staunch guarantee from Graphic Publishers Limited.

Are you one of those Canadians, who will sing, ('Oh Canada!' with enthusiasm)-and then go out and buy a foreign book ${ }^{4}$

Other imprints that must be considered, all of them in Ottawa, are: Canadian Biographies, Limited, used in one book in 1925; the Laurentian Press Syndicate, used for at least ten books published during 1926 and 1927 that were also issued under the Graphic imprint (The Laurentian Press Syndicate used sheets printed from Graphic plates and cancelled the first gathering, replacing it with new preliminary matter.); and Ariston Publishers Limited, a subsidiary of Graphic which issued two books in 1930 under the personal direction of Frederick Philip Grove, employed by Graphic between 1929 and I93I. Another associated and prolific enterprise was Henry C. Miller's vanity imprint, Ru-Mi-Lou Books, which operated between 1928 and 1930 and published at least ten books. With Ru-Mi-Lou, Miller continued to use distinctive design traits similar to those of his Graphics: the thunderbird device was replaced by another Indian motif, and flashy endpapers were designed by Douglas Leechman. In a 1930 pamphlet Miller described, the Ru-Mi-Lou operation:

This company is owned solely by H.C. Miller, who was the original founder of The Graphic Publishers Limited. Severing his connection entirely with this firm in 1929, he is now engaged in publishing (with financial assistance from the authors) a better class of Canadian books - produced entirely in Canada by Canadian workmen with Canadian materials. Private editions, whether de luxe or not, will receive his personal attention - and the comments his work received some years ago from the New York papers, means that they will be commendable from start to finish. ${ }^{5}$

By the end of 1929 Miller was permanently disassociated from the firm he founded, and Graphic moved its total operation from Ottawa to the suburb of 
Overbrook $^{6}$ and another imprint intricately related to Graphic made its appearance. Overbrook Press seems to have been the controlling faction's answer to Miller's Ru-Mi-Lou Books. It is noteworthy that Overbrook Press, which issued at least six titles, published a volume of verse by W.E.E. Ross, who, after Frederick Philip Grove, was Graphic's most significant author. Attention should also be drawn to the Carillon Book Club. While not a publisher, the enterprise was associated with Graphic and was probably started by Miller.7 Two previously published Graphic books, Grove's A Search for America and Watson Kirkconnell's European Elegies, were issued by Carillon in the Club's characteristic blue casings and blue and white endpapers.

What are some of the other aspects of Graphic Publishers that complicate the work of the bibliographer beyond what might be expected of a twentiethcentury trade publisher? First the typography: up until 1929 Graphic's output was set on Miller's Monotype equipment ${ }^{8}$ using one of five different faces. It is interesting to note that Miller, during one of his periodic financial crises, explained the delay in publishing $A$ Search for America by saying that he was waiting for a late shipment of new Monotype matrices; ${ }^{9} \mathrm{Grove}^{\prime} \mathrm{s}$ work was set in a face that had not been used by Graphic before.

Miller was a printer by trade before he entered the publishing world, and the books that appeared during his regime are distinctive, if not distinguished. (Grove said that Graphic Publishers produced ugly books, ${ }^{10}$ and to a certain extent he was right.) Miller's printer's mark, a swash ' $M$ ', appears on the verso of many title leaves of both Graphic and Ru-Mi-Lou books. Also typical of the Miller period, and of some help to the bibliographer, is a colophon that was used in some of the Graphic books between 1926 and 1929 detailing, among other things, the paper, typeface, and binding. Miller seems to have been directly influenced by Alfred A. Knopf of New York in various aspects of Graphic book design and production. The familiar Knopf colophon phrase, 'A note on the type in which this book is set', recurs in many Miller books. With Miller's departure from the firm, Monotype ceased to be used and the helpful colophons were discontinued. During the changeover in 1929, Intertype equipment and new printing presses were acquired for the Overbrook facility. ${ }^{11}$

There are no true second editions in either Graphic's or its associated imprints' output. However, there were six printings of MacDonald's Out of the Wilderness between 1926 and 1929; Grove's A Search for America and Macbeth's Land of Afternoon went through two printings each. All the printing done during the seven years took place in the Ottawa area except for Kirkconnell's The Tide of Life, published by Ariston in 1930: it was printed by Warwick Bros. \& Rutter Ltd. in Toronto. The size of Graphic books was quite uniform, although not without exception: approximately $19 \times 13 \mathrm{~cm}$., gathered in $8 \mathrm{~s}$. 
As with typography and printing, the casing of Graphic books and some associated imprints changed from 1929 to 1930 when the Overbrook plant installed case-making equipment. ${ }^{12}$ But it is not surprising that, as with many twentieth-century Canadian books, the casing of Graphic books is one of the more elusive, more difficult to verify, and hence more complex aspects of description: variants and issues abound. Of the sixty-three books with the Graphic imprint, all but three were issued in cloth casings and I believe that all but three of these cloth-cased books were issued in dust jackets. The fabric, colour, design, decoration, and endpapers often vary. In some instances it is quite simple to determine primary and secondary casings for particular books; for some other variations we will probably never know the reasons - if there were reasons. Some of the artists who created the jackets, decorative endpapers, and cover designs are easily identified; others have yet to be detected. Both C.W. Jefferys and Thoreau MacDonald did some work for Graphic in addition to the regulars: Alan Beddoe, Gordon Fairbairn, and Fred Lewis.

Copies of the majority of the cloth-cased Graphic books also exist in wrappers, but as far as can be ascertained only one title was marketed in both paper and hard cover: Burpee's The Discovery of Canada. The other wrappers fall into two general classes: plain wrappers printed in black on the front and wrappers cut down from the dust jackets designed for the cloth-cased issues. These wrappered copies may have been proof and / or review copies. Some of them, as well as some of the cloth variants, may have been bound or rebound from unsold copies of Graphic books - bound, unbound, and in sheets - that were remaindered as part of the estate of Graphic Publishers when the firm went bankrupt. In passing it should be noted that both Carillon Book Club and Laurentian Press Syndicate issues of Graphic titles have their own separate, distinctive casings.

Edward St. John has written, 'The Graphic Publishers have left an indelible mark upon the publishing scene in Canada. Their significant output will secure their position in the history of Canadian publishing.' ${ }^{13}$ I have attempted here to touch on a few aspects and problems in identifying and describing this output. Though the twentieth century may not provide the same playground for bibliographers as earlier periods, there are both old and new problems that need to be analyzed and resolved in describing the books of our time. Even a relatively short-lived publisher such as Graphic demonstrates what some of these problems are. 


\section{Checklist of Graphic Publishers and Associated Imprints ${ }^{14}$}

Armstrong, Rinaldo William. The Salt of the Earth: A Study in Rural Life and Social Progress. I930.

-. Sex, Temperance and Right Thinking. 1931.

Benson, Nathanial Anketell Michael. Modern Canadian Poetry. 1930.

- Three Plays for Patriots. 1930.

Bird, William Richard. Private Timothy Clancy. 1930.

Blackburn, Victoria Grace. The Man Child, by Grace Blackburn ('Fan-Fan'). 1930.

Bourinot, Arthur Stanley. Ottawa Lyrics, and Verses for Children. I929.

- Pattering Feet: A Book of Childhood Verses. 1925.

Brooke, Frances Moore. The History of Emily Montague, by the Author of Lady Julia Mandeville. I93I.

Burpee, Lawrence Johnston. The Discovery of Canada. 1929.

- Jungling in Jasper. 1929.

Campbell, Austin. The Rock of Babylon: Adventure in an Ancient City. 193I.

Carey, Douglas. See Dennis, John Douglas Carey

Carleton, Veros. See Cox, Amy

Cheadle, Walter Butler. Cheadle's Journal of a Trip across Canada. I93I.

Cox, Amy. The House of Temptation, by Veros Carleton [pseud.] I93I .

Clark, Duncan. See Craig, Mary Coad

Craig, Mary Coad. The Two Decanters. Written for his Wife by Duncan Clark, M.D. [pseud.] 1930.

Cunningham, Louis Arthur. The King's Fool: A Fascinating Novel of Love, Adventure and Intrigue in the Time of Louis XV. I93r.

. Yvon Tremblay: An Acadian Idyll. 1927.

Davisson, Walter P. Pooling Wheat in Canada. 1927.

Deacon, William Arthur. The Four Jameses. 1927.

- Open House. Edited by William Arthur Deacon and Wilfred Reeves. I931.

- Poteen: A Pot-Pourri of Canadian Essays. 1926.

Delafosse, Frederick Montague. English Bloods, by Roger Vardon [pseud.] I930.

Denison, Merrill. Boobs in the Woods: Sixteen Sketches by One of Them. I927.

Dennis, John Douglas Carey. The Raven's Feathers, by Douglas Carey [pseud.] 1930.

The Scorpion: A Limehouse Mystery, by Douglas Carey [pseud.] 1931.

Dill, W.S. See Macbeth, Madge Hamilton Lyons

Edgar, William Wilkie. See Saint Thomas d'Aquin, Sister. Duets in Verse.

Fan-Fan. See Blackburn, Victoria Grace

Fewster, Ernest Philip. My Garden Dreams. 1926.

Francisco, Ramon. See Whitehouse, Francis Cecil

Gomery, Percy. Curve, Go Slow: A Romance of the Pacific Coast Highway. 1927.

Grove, Frederick Philip. A Search for America. 1927. Two printings: 1927, 1928.

Kirkconnell, Watson. European Elegies: One Hundred Poems Chosen and Translated from European Literature in Fifty Languages. 1929.

Knox, Gilbert. See Macbeth, Madge Hamilton Lyons

Lahontan, Louis Armand de Lom d'Arce, baron de. Lahontan's Voyages. 1932.

Le Bourdais, Donat Marc. Northward on the New Frontier. I93I.

Low, Mildred. 'If I Forget Thee': A Souvenir of the Centenary of Ottawa, Capital of Canada, 1826-1926. 1926.

Macbeth, Madge Hamilton Lyons. Curiosity Rewarded: A Dialogue between Gilbert Knox [pseud.] and the Curious Public. 1926. 
Macbeth, Madge Hamilton Lyons. The Land of Afternoon: A Satire, by Gilbert Knox [pseud.] 1925. Two printings in 1925.

- The Long Day: Reminiscences of the Yukon, by W.S. Dill [pseud.] 1926.

- Over the Gangplank to Spain. I93r.

- Shackles. 1926.

MacDonald, Wilson Pugsley. Out of the Wilderness. 1926. Six printings from 1926 to I929.

McElhinney, Mark Gamble. Morning in the Marsh: Poems for Lovers of the Great Outdoors. 1927.

McGillivray, Carrie Holmes. The Shadow of Tradition: A Tale of Old Glengarry. 1927.

McIlwraith, Jean Newton. Kinsmen at War. 1927.

Meredith, Alden G. Mary Rosedale and Gossip of 'Little York'. 1928.

O'Grady, Daniel Charles. Cosmology: A Cross Section: Footnotes in the Philosophy of Nature. 1932.

O'Hagen, Thomas. Intimacies in Canadian Life and Letters. 1927.

Pedley, James Henry. Only This: A War Retrospect. 1927.

Philip, Alex. The Painted Cliff. 1927.

- Whispering Leaves. I93I.

Pyke, Magnus, 'Go West, Young Man, Go West.' 1930.

Reeves, Wilfred. See Deacon, William Arthur. Open House.

Rhodenizer, Vernon Blair. A Handbook of Canadian Literature. 1930.

Roberton, Thomas Beattie. The Fighting Bishop: John Strachan, First Bishop of Toronto, and Other Essays in His Times. 1926.

Rogers, Charles Gordon. Ballads O'Barleycom. 1925.

Saint Thomas d'Aquin, Sister. Duets in Verse, French and English, by Marie Sylvia [pseud.] and William Wilkie Edgar. 1929.

Steiner, Florence B. Toy Ships: Poems for Children. 1926.

Sylvia, Marie. See Saint Thomas d'Aquin, Sister

Vardon, Roger. See Delafosse, Frederick Montague

Walker, Major Benson. On Down the Road. 1928.

- 'Scottie': A True Story of a Dog for Young.Folks. 1927.

Watson, Robert. A Boy of the Great North West. 1930.

- Canada's Fur-Bearers: Little Nature Studies in Verse. 2nd ed. 1925.

. How to Write, by Those Who Can. 1928.

Whitehouse, Francis Cecil. Plain Folks: A Story of the Canadian Prairies. 1926.

. Rebels, and Other Love Poems, by Francisco Ramon [pseud.] 1929.

Williams, Flos Jewell. Broken Gods. I930.

. New Furrows: A Story of the Alberta Foothills. 1926.

Writers Club, Toronto. Canadian Writer's Market Survey. 1931.

ARISTON PUBLISHERS

Kirkconnell, Watson. The Tide of Life, and Other Poems. I930.

Wallis, Ella Bell. The Exquisite Gift. 1930.

CANADIAN BIOGRAPHIES LIMITED

Prominent People of the Province of Ontario. I925. 


\section{CARILLON BOOK CLUB OF CANADA}

Grove, Frederick Philip. A Search for America. Ottawa: Graphic Publishers, 1927. From Ist printing.

Kirkconnell, Watson. European Elegies: One Hundred Poems Chosen and Translated from European Literatures in Fifty Languages. Ottawa: Graphic Publishers, I928.

\section{LAURENTIAN PRESS SYNDICATE}

Cunningham, Louis Arthur. Yvon Tremblay: An Acadian Idyll.

Deacon, William Arthur. The Four Jameses.

\section{- Poteen: A Pot-Pourri of Canadian Essays.}

Gomery, Percy. Curve, Go Slow: A Romance of the Pacific Coast Highway.

Macbeth, Madge Hamilton Lyons. The Land of Afternoon: A Satire, by Gilbert Knox [pseud.] From end printing.

- The Long Day: Reminiscences of the Yukon, by W.S. Dill [pseud.]

McIlwraith, Jean Newton. Kinsmen at War.

Philip, Alex. The Painted Cliff.

Roberton, Thomas Beattie. The Fighting Bishop: John Strachan, First Bishop of Toronto, and Other Essays in His Times.

Whitehouse, Francis Cecil. Plain Folks: A Story of the Canadian Prairies.

Williams, Flos Jewell. New Furrows: A Story of the Alberta Foothills.

(Note: Laurentian Press Syndicate issues were undated.)

OVERBROOK PRESS

Chadwick, Ethel. If the Cap Fits - ? [193I?]

Edelstein, Hyman. Selected Poems. I931.

Fewster, Emest Philip. White Desire. and ed. I930.

O'Connor, Austin. The Highway Traffic Act: A Digest of the Cases on Highway Traffic and Motor Vehicles Dealt with in Ontario Courts and the Supreme Court of Canada up to and including December 15th. 1931, with Related Sections of the Negligence Act and Certain Sections of the Criminal Code and the Insurance Act. I931.

Perry, Martha Eugenie. The Girl in the Silk Dress, and Other Stories. I931.

Ross, William Wrightson Eustace. Laconics, by E.R. [pseud.] I930.

Wharton, Lewis. Songs of Carthage, and Other Poems. I930.

RU-MI-LOU BOOKS

Calder, Sarah Isabell Lowry. Poems. 1928.

Carr, Amy. The Swinging Pendulum. 1928.

English, Arthur. Ogygia: A Tale of Old Newfoundland. I930.

Lewis, Harrison Flint. The Natural History of the Double-Crested Cormorant

(Phalacrocorax auritus auritus (Lesson)). 1929.

Lewis, Susan Victoire. Collected Verse. 1929.

Macdonald, John James. Poems and Essays, by John J. Macdonald (James McRae). I928. McRae, James. See Macdonald, John James

Montigny, Louvigny Testard de. Copyright in Canada in 1930: Report of the Copyright Committee of the Canadian Authors' Association. 1930.

Mowat, Grace Helen. Funny Fables of Fundy, and Other Poems for Children. I928.

Peteson, Charles Walter. The Fruits of the Earth: A Story of the Canadian Prairies. I928. Publish Your Own Book. I928. Not seen. 


\section{Notes}

I. The text of this article is based on a paper delivered at the Annual Meeting of the Bibliographical Society of Canada in Ottawa in June 1979. Acknowledgement is gratefully made to two unpublished works on the Graphic Publishers: Erik J. Spicer's 1959 research paper, 'The Graphic Publishers Limited, Ottawa, Ontario, Canada, 1924-1932' and Edward St. John's 1974 Master's thesis, 'The Graphic Publishers Limited, 1925-1932'.

2. Letter from Henry C. Miller to Mrs. Frederick Philip Grove, Nov. 9, 1926, Frederick Philip Grove Papers, Elizabeth Dafoe Library, University of Manitoba, quoted by Edward St. John, 'The Graphic Publishers Limited, 1925-1932' (Master's thesis, Carleton University, 1974), p. 18.

3. Imprints are not transcribed in quasi-fascimile.

4. Character (Ottawa: Graphic Publishers [I93I?]), p. [3].

5. Louvigny de Montigny, Copyright in Canada in 1930 (Ottawa: Ru-Mi-Lou Books, 1930), p. [18] (i.e., rear wrapper).

6. St. John, p. 62.

7. Ibid., p. 34 .

8. Erik J. Spicer, 'The Graphic Publishers Limited, Ottawa, Ontario, Canada, r9241932' (Special Research for the Department of Library Science, University of Michigan, 1959l, p. [r].

9. Letter from Henry C. Miller to Frederick Philip Grove, March I3, 1927, Frederick Philip Grove Papers, Elizabeth Dafoe Library, University of Manitoba, quoted by St. John, p. 2 r.

Io. Frederick Philip Grove, In Search of Myself (Toronto: Macmillan, I946), p. 4II .

II. Spicer, p. I9.

12. Ibid., pp. 19-20.

I3. St. John, p. Io6.

I4. Only brief descriptions are given in this checklist; Graphic Publishers' catalogues, promotional material, offprints, and ephemera have been excluded; a full descriptive bibliography will be found in the forthcoming A History and Bibliography of the Graphic Publishers, by Edward St. John and David B. Kotin (Willowdale: North York Public Library). Additions and / or corrections to this checklist are solicited and should be sent to the Canadiana Collection, North York Public Library, 35 Fairview Mall Dr., Willowdale, Ont. M2J 4s4. 